\title{
Polyfunctional properties of oat $\beta$-glucan in the composition of milk-vegetable ice cream
}

\section{Victoria Sapiga ${ }^{1}$, Galina Polischuk ${ }^{1}$, Magdalena Buniowska ${ }^{2}$, Iryna Shevchenko ${ }^{1}$, Tetiana Osmak ${ }^{1}$}

\author{
1 - National University of Food Technologies, Kyiv, Ukraine \\ 2 - University of Rzeszow, Rzeszow, Poland
}

Keywords:

Ice cream

$\beta$-glucan

Vegetable

Puree

Viscosity

thixotropic

Foam

Article history:

Received

25.03.2021

Received in

revised form

12.09.2021

Accepted

30.12.2021

Corresponding author:

Tetiana Osmak

E-mail:

osmaktg@ukr.net

DOI:

$10.24263 / 2304-$

974X-2021-10-4-

5

\section{Abstract}

Introduction. The aim of the work was to study the effect of oat $\beta$-glucan on the viscosity-speed indicators of mixtures and physicochemical characteristics of milk-vegetable ice cream.

Materials and methods. Milk-vegetable ice cream with a mass fraction of fat $3 \%$ and oat $\beta$-glucan in the amount of 0.5 $1.0 \%$ with a stabilization system and without, as well as control samples of classic milk ice cream, were prepared. Rotational viscometry and well-known methods for studying the resistance to melting, overrun and ice cream dispersion of the air phase were used.

Results and discussion. The structuring ability of $\beta$-glucan in ice cream with low fat and dry matter content was studied. The effective viscosity of ice cream mixtures with $\beta$-glucan in the amount of $0.5-1.0 \%$ is in the range of recommended values. Mixtures of milk ice cream with $\beta$-glucan are characterized by thixotropic ability, which is confirmed by the high degree of restoration of the destroyed structure. Combined use of $\beta$-glucan and fermented vegetable puree containing soluble pectin and softened vegetable fibers could significantly improve the viscosity-speed indicators of mixtures: the effective viscosity increases by $11.5-15.9 \%$, the degree of recovery in on average by $10 \%$. Low-fat milk-vegetable ice cream with a $\beta$-glucan content of $0-1.0 \%$ acquires a creamy consistency. The increase in overrun and resistance to melting of ice cream with $\beta$-glucan is due to the formation of a specific secondary foam microstructure that is characterized by the presence of an additional framework of microbubbles, which wraps larger air inclusions and gives them additional mechanical stability during heating. Thus, it was proved that $\beta$-glucan is a universal ingredient that can, in addition to enrichment, perform a structuring and stabilizing function in the composition of low-fat milk-vegetable ice cream.

Conclusions. Studies prove the feasibility of using oat $\beta$ glucan in the amount of $0.75-1.0 \%$ in the composition of low-fat milk-vegetable ice cream. 


\section{Introduction}

Ice cream is a structured multicomponent food product that is also an emulsion, foam and suspension (Landikhovskaya et al., 2021; Syed et al., 2018). High-calorie ice cream with a fat content of at least $10-12 \%$ is stably in high demand due to its rich creamy taste, creamy consistency, and high resistance to melting (Rolon et al., 2017). On the one hand, low-fat ice cream is of increasing interest to consumers as a new trend among low-calorie foods (El-Zeini et al., 2016). On the other hand, the low content of fat $(\leq 3 \%)$ and dry matter $(\leq 30 \%)$ in ice cream has a negative effect on its quality. Excess water causes thinning of the consistency of ice cream and is the cause of polydisperse distribution of the air phase, which worsens the sensory characteristics of ice cream (Landikhovskaya et al., 2020; Goff, 2019).

The effective viscosity of ice cream mixes is one of the most important characteristics, which determines the patterns of formation of the structure of ice cream throughout the technological process of its production. An equally important characteristic is the ability of ice cream after freezing to restore the structure in a static state after the formation of portions before hardening (Bass et al., 2017). To form the appropriate rheological characteristics of ice cream mixes, the components that capable to bind water and structure multi-component mixes were used. Such compounds include polysaccharides, in particular maltodextrin, inulin, polydextrose, gum, pectin and others (Alvarez et al., 2008; Armi Aghdaei et al., 2012; Chiampo et al., 1996; Javidi et al., 2016; Tvorogova et al., 2018; Zghurskyi et al., 2011).

Recently, scientists have shown special interest in $\beta$-glucans - polysaccharides formed from Dglucose monomers connected by beta-glycosidic bonds. This multifunctional ingredient is used in preparation of low-fat foods, as a source of soluble prebiotic fiber. Fermentation of fiber produces a substrate for the microbiota in the large intestine, which further affects digestive function and metabolism of cholesterol and glucose, as well as the immune system and other systemic functions (Bashir et al., 2017; Giavasis, 2014).

$\beta$-glucans from barley, oat, wheat, yeast are not only mimetics of fat, but also bind water, structure mixtures, increase overrun and resistance to melting of ice cream. Each type of $\beta$-glucan differs in molecular weight and structure, which determine its solubility, physiological and technological action (Abdel-Haleem et al., 2015). $\beta$-glucans as macromolecular compounds affect the viscosity characteristics and rheological behavior of aqueous solutions (Irakli et al., 2004). It was found that preparations of polysaccharides of Pleurotus ostreatus, containing $\beta$-glucans, in the amount of $0.1 \%$, improve the structural and mechanical properties of fermented milk drinks (Antontceva et al., 2019).

The feasibility of using beta-glucans of various origins in low-fat ice cream has been scientifically confirmed (Aljewicz et al., 2020). Highly purified oat $\beta$-glucans increased the overrun of ice cream. It was found that (1-3) $\beta$-glucan of linear structure obtained from Agrobacterium sp. bacteria is less effective compared to (1-3) (1-4) $\beta$-glucan from oat in the content range from 0.5 to $1.0 \%$. (Irakli et al., 2004). However, some important viscosity-speed characteristics of mixtures and physicochemical characteristics of ice cream have not been studied yet, including the combination with pectin-containing components. This is what outlines the topicality of a deeper study of this issue.

The purpose of the research is to study the functional and technological properties of oat $\beta$-glucan in the composition of low-fat milk-vegetable ice cream.

To achieve this purpose, it is necessary to solve the following tasks:

- To identify the features of structuring mixtures of low-fat ice cream with $\beta$-glucan;

- Check the structuring ability of $\beta$-glucan in the presence of pectin-containing vegetable raw materials;

- To study the effect of $\beta$-glucan from oats on resistance to melting and the content and dispersion of the air phase in low-fat milk ice cream. 


\section{Materials and methods}

\section{Materials and sample preparation}

The prescription composition of the studied ice cream samples is determined by the following requirements:

- The dry matter content should be from 27.5 to $30.0 \%$, which is typical for the chemical composition of low-fat ice cream;

- Mass fraction of fat should be $3.0 \%$, which corresponds to its content in low-fat ice cream;

- Mass fraction of dry skimmed milk residue should be $10.0 \%$, which ensures the completeness of the milk taste in ice cream with low fat content;

- Mass fraction of sugar should be $15.0 \%$, which provides the traditional degree of sweetness and maintains the dry matter content in ice cream not less than $27.5 \%$;

- Mass fraction of the stabilization system cremodan ${ }^{\circledR}$ si 320 (manufacturer - dupont danisco, denmark) should be $0.7 \%$, which corresponds to its recommended content for this type of ice cream according to the manufacturer's recommendations;

- Mass fraction of the composition of classic hydrocolloids (guar gum, locust bean gum, carrageenan) should be $0.6 \%$, according to the recommendations for low-fat ice cream;

- Mass fraction of $\beta$-glucan oat $70 \%$ (amulyn, china) should be from 0.5 to $1.0 \%$, which is consistent with existing recommendations for the use of such additives in ice cream (Aljewicz et al., 2020);

- Mass fraction of table beet puree with high content of soluble pectin was selected in the amount of $15.0 \%$, according to existing recommendations (Borisova et al., 2014), taking into account the sensory characteristics of table beets and not exceeding the maximum possible content of vegetable puree in ice cream $(\leq 35 \%)$ (Polishchuk et al., 2021). The puree was previously subjected to enzymolysis using the pectolytic enzyme pectolad (Enzim Biotech, Ukraine) (Sapiga et al., 2021).

Cow's milk (3.2\% fat, 9.0\% DSMR) and skimmed milk powder produced in Ukraine were used as a source of dry skimmed milk residue (10.0\%) and milk fat $(2.0 \%)$ in ice cream recipes.

It was studied 2 control mixtures with stabilizers:

- Control 1 was a mixture with a composition of classical hydrocolloids "guar gum + carob gum + carrageenan" $(0.6 \%)$;

- Control 2 was a mixture of CremodanßSI $320(0.7 \%)$;

It was studied 6 samples without stabilizers with $\beta$-glucan:

- Samples 1-3 were mixtures with $\beta$-glucan in the amount of $0.5,0.75$ and $1.0 \%$, respectively;

- Samples 4-6 were mixtures with $\beta$-glucan $(0.5,0.75$ and $1.0 \%$, respectively) and vegetable puree $(15 \%)$.

Milk-vegetable mixtures were obtained by sequentially mixing the recipe ingredients at a temperature of $(35 \pm 5){ }^{\circ} \mathrm{C}$, followed by their pasteurization at a temperature of $(85 \pm 2){ }^{\circ} \mathrm{C}$ for $120 \mathrm{~s}$. Then the mixtures were homogenized under pressure (12.0 \pm 1.0$) \mathrm{mPa}$ using a laboratory homogenizer-dispersant model 15M-8TA "Lab Homogenizer \& Sub-Micron Disperser" (GAULIN CORPORATION, Massachusetts, USA), cooled to a temperature of $(4 \pm 2){ }^{\circ} \mathrm{C}$ and stored before freezing for 12 hours. 
Prototypes of ice cream were obtained using a freezer of periodic action brand FPM3.5 / 380-50 "Elbrus-400" (JSC "ROSS", Ukraine). The temperature of the mixtures before freezing was $(4 \pm 2)^{\circ} \mathrm{C}$. The temperature of the soft ice cream at the outlet of the freezer was minus $(4 \pm 0.5){ }^{\circ} \mathrm{C}$. Freezing was performed in two stages:

- In the first stage, the mixture was cooled in a cooling cylinder to a temperature of minus

$1{ }^{\circ} \mathrm{C}$ at a speed of the stirrer scraper type $4.5 \mathrm{~s}^{-1}$ for $120 \mathrm{~s}$;

- In the second stage, the mixture was freezed at a stirrer speed of $9 \mathrm{~s}^{-1}$ for $180 \mathrm{~s}$.

Ice cream samples were cooled and stored in a Caravell A / S freezer (Denmark) at minus $(22 \pm 1){ }^{\circ} \mathrm{C}$ during the study. Samples of the same chemical composition were made at least 2 times.

\section{Research methods}

During rheological measurements of milk mixtures and milk-vegetable mixtures, the effective viscosity of practically intact structure, the viscosity of extremely destroyed structure, as well as the ability of these systems to restore it spontaneously after ultimate destruction of the structure were determined, according to V.N. Matveenko and Ye.O. Kirsanova (Matveenko et al., 2011).

The viscosity characteristics of ice cream mixtures were determined on a rotary viscometer with a cylinder-cylinder measuring system by measuring the kinetics of deformation. Shear stress measurements $\tau(\mathrm{Pa})$ were performed at a temperature of $20^{\circ} \mathrm{C}$ at twelve values of the shear rate gradient $(\gamma)$ in the range from 3 to $1312 \mathrm{~s}^{-1}$ in forward and reverse (Bass et al., 2017). At some stages of the study, the maximum effective viscosity of the practically unstructured structure $\left(\gamma=3 \mathrm{~s}^{-1}\right)$, the minimum effective viscosity of the extremely destroyed structure $\left(\gamma=1312.2 \mathrm{~s}^{-1}\right)$ and the effective viscosity of the restored structure were recorded $\left(\gamma=3 \mathrm{~s}^{-1}\right)$.

Thixotropic ability, which is characterized by the degree of restoration of the structure, was determined as a percentage of the difference between the values of effective viscosity of virtually undamaged structure in the shear rate gradient $\left(\gamma=3 \mathrm{~s}^{-1}\right)$ and effective viscosity in reverse measurement with the same shear rate gradient (Polishchuk et al., 2014).

The overrun of soft ice cream was determined by the weight method by the difference between the mass of the samples of the same volume of the mixture and ice cream, expressed as a percentage, according to the formula:

$$
S=\frac{M_{1}-M_{2}}{M_{2}} \cdot 100,
$$

where $\mathrm{M}_{1}$ is the mass of the beaker with the mixture, $\mathrm{g}$;

$\mathrm{M}_{2}$ - weight of the beaker of ice cream, $\mathrm{g}$.

The resistance to melting of ice cream samples was analyzed by a modified method described by (Roland et al., 1999). Cylinders of $50 \mathrm{~mm}$ high and $35 \mathrm{~mm}$ wide were cut out of solid ice cream after pre-heating at a temperature of minus $12{ }^{\circ} \mathrm{C}$ using a special probe. At room temperature $(22 \pm 2){ }^{\circ} \mathrm{C}$, the formed samples were placed on a sieve, under which there were measuring cylinders with funnels. The melting characteristic of ice cream was taken as the time during which $10 \mathrm{~cm}^{3}$ of liquid mixture was separated.

For microstructural analysis of the air structure, the ice cream sample was taken from the center of the portion from at least three different places, at least $3 \mathrm{~cm}$ from the ice cream surface, placed at $(20 \pm 1){ }^{\circ} \mathrm{C}$ in Goryaev's chamber and covered with a cover glass. Microphotographs were obtained using an Olympus CX 41 light microscope and a camera (Tvorogova et al., 2018). 


\section{Results and discussion}

\section{Study of viscosity-speed characteristics of ice cream mixes with vegetable purees}

Table 1 shows viscosity-speed characteristics of the studied ice cream mixes.

Effective viscosity $(\mathrm{mPa} \cdot \mathrm{s})$ of ice cream mixtures with variable shear rate gradient

Table 1

$(\mathrm{P} \geq \mathbf{0 . 9 5} ; \mathbf{n}=\mathbf{3})$

\begin{tabular}{|c|c|c|c|c|c|}
\hline \multirow{2}{*}{$\begin{array}{c}\text { Sample } \\
\text { number }\end{array}$} & $\boldsymbol{\gamma} \mathbf{1}$ & $\boldsymbol{\gamma} \mathbf{S h e a r}$ rate gradient & $\boldsymbol{\gamma} \mathbf{3}$ & $\begin{array}{c}\text { Time of ultimate } \\
\text { destruction of the } \\
\text { structure }(\boldsymbol{\gamma} \mathbf{2}) \mathbf{s}\end{array}$ & $\begin{array}{c}\text { Degree of } \\
\text { restoration of the } \\
\text { structure, \% }\end{array}$ \\
\hline Control 1 & $410.2 \pm 11.6$ & $25.1 \pm 1.1$ & $210.2 \pm 9.1$ & $300.0 \pm 8.2$ & 52.5 \\
\hline Control 2 & $652.2 \pm 15.6$ & $26.0 \pm 1.1$ & $413.2 \pm 11.8$ & $396.6 \pm 7.2$ & 63.4 \\
\hline 1 & $380 \pm 10,3$ & $34.5 \pm 1.0$ & $201.1 \pm 6.1$ & $360.0 \pm 8.1$ & 52.9 \\
\hline 2 & $440.2 \pm 15.6$ & $40.1 \pm 1.1$ & $239.5 \pm 11.8$ & $408.8 \pm 11.2$ & 55.7 \\
\hline 3 & $499.7 \pm 16.1$ & $46.2 \pm 1.7$ & $306.4 \pm 10.0$ & $420.0 \pm 10.2$ & 62.6 \\
\hline 4 & $425.5 \pm 12.8$ & $38.1 \pm 1.4$ & $295.4 \pm 10.2$ & $372.2 \pm 9.1$ & 69.4 \\
\hline 5 & $510.3 \pm 13.7$ & $47.4 \pm 1.3$ & $365.3 \pm 11.0$ & $414.4 \pm 9.2$ & 71.6 \\
\hline 6 & $557.3 \pm 17.5$ & $48.3 \pm 2.0$ & $402.0 \pm 9.3$ & $426.1 \pm 12.2$ & 72.1 \\
\hline
\end{tabular}

Symbols:

$\gamma 1$ - shear rate gradient in the direct course of measurement $\left(3 \mathrm{~s}^{-1}\right)$;

$\gamma 2$ is the maximum shear rate gradient $\left(1312.2 \mathrm{~s}^{-1}\right)$;

$\gamma 3$ is the gradient of the shear rate $\left(3 \mathrm{~s}^{-1}\right)$ at the reverse of the measurement.

According to the results of the study, the effective viscosity of all samples of mixtures at the beginning of the measurement was not lower than the recommended values for ice cream mixtures of different chemical composition (350-850 $\mathrm{mPa} \cdot \mathrm{s}$ ) (Kosoi et al., 2001; Nadtochii et al., 2016; Tvorogova et al., 2018). At the same time, it should be noted that $\beta$-glucan only at a content of $0.75 \%$ approached the values of effective viscosity characteristic of the control mixture 1 . With increasing $\beta$-glucan content, the structuring of mixtures increased due to the probable increase in low energy functional groups of polysaccharide macromolecules. However, it is interesting that the time of ultimate destruction of the structure before equilibrium and the viscosity of mixtures with $\beta$-glucan at the maximum shear rate gradient are greater in comparison with control samples. This effect can be explained by the greater number of sites of successive cellotriose units those "crosslink" $\beta$-glucan macromolecules into the gel matrix (Du et al., 2019).

Also of great interest is the effect of pectin-containing vegetable puree on the nature of the changes in effective viscosity throughout the rheometric measurement cycle. Fermented beet puree in the amount of $15 \%$, which contains about $1.0 \%$ of soluble pectin (Sapiga et al., 2021), ensures its presence in the composition of milk-vegetable mixtures in the amount of up to $0.15 \%$. The specific structuring ability of $\beta$-glucan $(0.5-1.0 \%)$ and pectin $(0.15 \%)$ in their joint action allows to increase the thixotropic capacity of ice cream mixtures from 52.9 $62.6 \%$ to $69.4-72.1 \%$. This indicates a possible mutually selective synergism of polysaccharides, which is important for stabilizing the structure of ice cream after the formation of portions of ice cream before its low-temperature freezing and storage. Probably, not the last role in increase of thixotropic ability of mixes of milk-vegetable, numerous 
mechanical contacts between the shredded vegetable fibers are played. It should be noted that the detected effect requires further detailed study.

The most typical examples of the dynamics of changes in the effective viscosity of ice cream mixes during the measurement are shown in Figure 1.

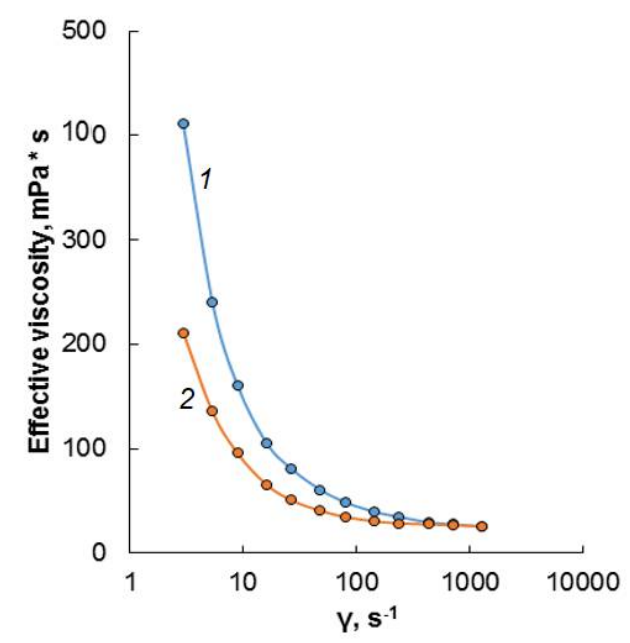

a

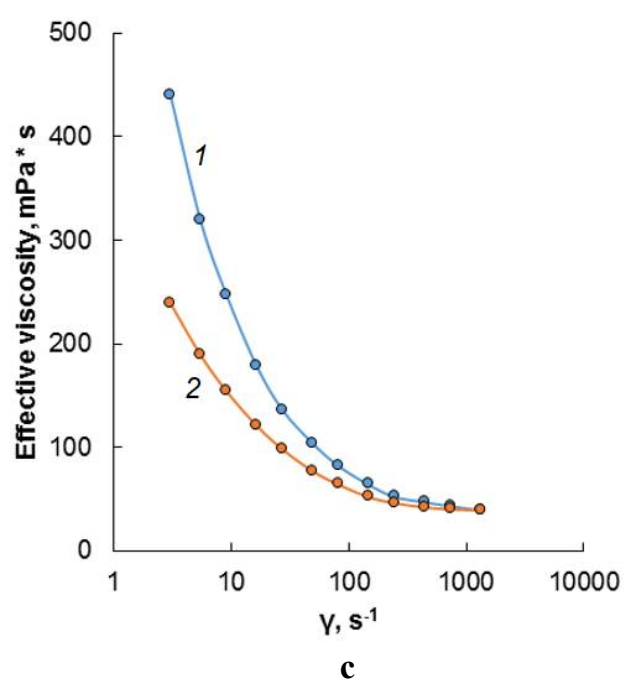

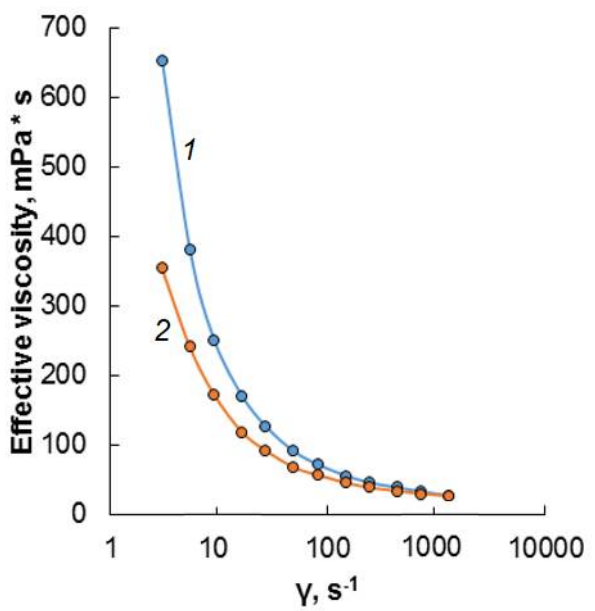

b

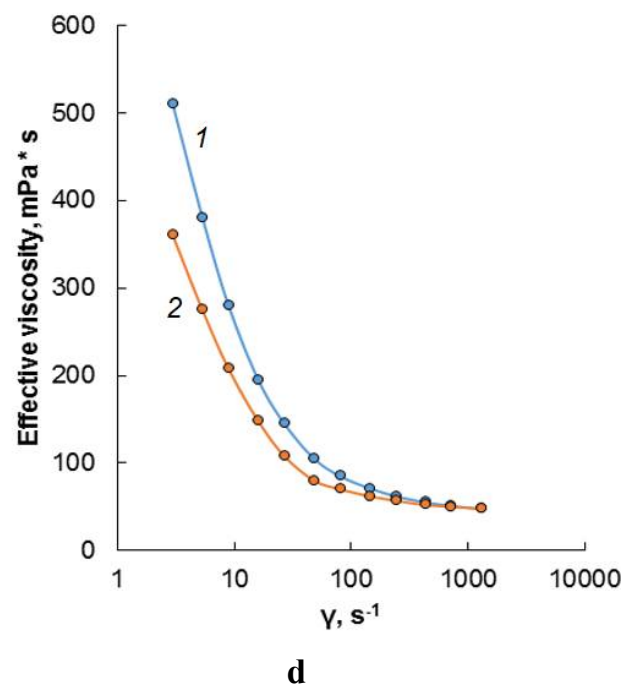

Figure 1. Viscosity-speed characteristics of ice cream mixes: a - control 1 ( $m i x$ with classic stabilizers);

b - control 2 (mixture with stabilization system Cremodan ${ }^{\circledR} S I$ 320); $\mathbf{c}$ - a mixture with $\beta$-glucan $(0.75 \%) ; d-a$ mixture with $\beta$-glucan $(0.75 \%)$ and vegetable puree $(15 \%)$ 1 - forward course; 2 - reverse course. 
Comparative analysis of the flow rheograms of two control and two experimental samples suggests that the process of destruction of the structure of systems with $\beta$-glucan is slower. This process occurs until the values of effective viscosity $\left(\gamma 2=1312.2 \mathrm{~s}^{-1}\right)$ are almost twice as large - up to $40.1 \mathrm{mPa} \cdot \mathrm{s}$ for sample 2 and up to $47.4 \mathrm{mPa} \cdot \mathrm{s}$ for sample 5, compared with control samples 1 and $2-25.1 \mathrm{mPa} \cdot \mathrm{s}$ and $26 \mathrm{mPa} \cdot \mathrm{s}$, respectively. Mixtures of milk and milk-vegetable ice cream can be attributed to systems with a pronounced coagulation structure with the detection of thixotropic properties. The latter characteristic is most pronounced for systems containing $\beta$-glucan.

The specific behavior of ice cream mixtures with $\beta$-glucan indicates the presence of low-energy coagulation-type bonds, including the content of vegetable raw materials. Due to the probability of the influence of the particle size of vegetable raw materials on the rheological characteristics of mixtures of dairy and vegetable with $\beta$-glucan, additionally studied sample 5 containing $0.75 \% \beta$-glucan and $15 \%$ vegetable puree:

- The mixture is not homogenized (sample 5a);

- The mixture is homogenized (sample 5b).

Figure 2 shows the effective viscosity of mixtures of both samples with the initial gradient of the shear rate at the forward stroke of the measurement $(\gamma 1)$ and the gradient of the shear rate at the reverse stroke at the end of the measurement $(\gamma 3)$.

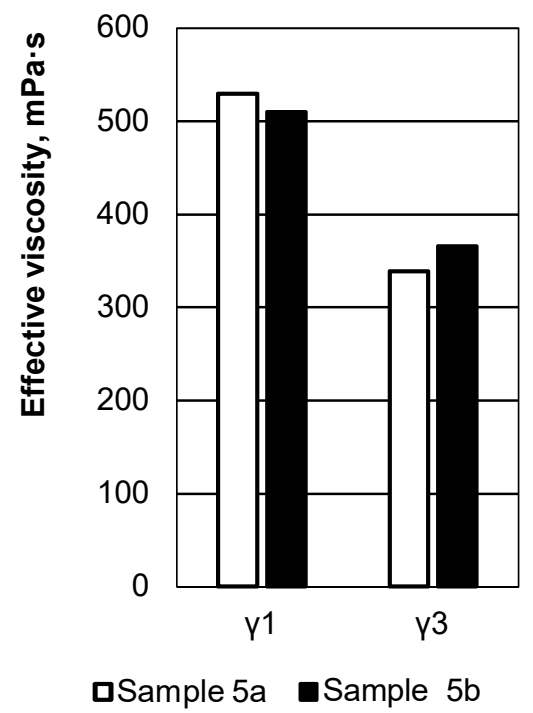

Figure 2. Effective viscosity of a mixture of non-homogenized milk and vegetable (sample 5a) and homogenized (sample 5b) at the beginning of the measurement (forward stroke, $\gamma 1=3 \mathrm{~s}^{-1}$ ) and at the end of the measurement (reverse stroke, $\gamma 3=3 \mathrm{~s}^{-1}$ )

A slight decrease in the effective viscosity of the homogenized mixture compared to the non-homogenized one was probably observed due to excessive grinding of the plant fibers, which partially lose the ability to form spatial frame grids. There is also a possibility of partial destruction of macromolecules of polysaccharides ( $\beta$-glucan, pectin) under the action of homogenization at a pressure of $(12.0 \pm 1.0) \mathrm{MPa}$. But it should be noted that the 
homogenized mixture to a greater extent showed the ability to restore the structure, which is a significant advantage for stabilizing the structure of ice cream before its formation and hardening. This characteristic is important for the choice of rational modes of operation of the equipment.

In view of this, there is a need for additional study of technological modes of the freezing process, in particular, the duration of freezing and whipping mixtures of ice cream with $\beta$-glucan. This will be taken into account in further research.

\section{Study of oat $\beta$-glucan effect on resistance to melting, content and dispersion of the air phase in low-fat dairy ice cream}

The rheological characteristics of ice cream mixes directly affect the physicochemical parameters of ice cream, in particular the overrun, resistance to melting and the state of the air phase in the product (Milliatti et al., 2018).

The different nature of the structuring of ice cream mixtures with $\beta$-glucan and without it may determine the specifics of the processes of formation and stabilization of dispersed systems of dairy ice cream. Therefore, the overrun, the degree of the air phase dispersion and the stability of the foam structure of ice cream with $\beta$-glucan and without it were studied. The overrun of control and experimental samples of soft ice cream at the outlet of the freezer, as well as the resistance to melting of hardened ice cream are shown in Figure 3.

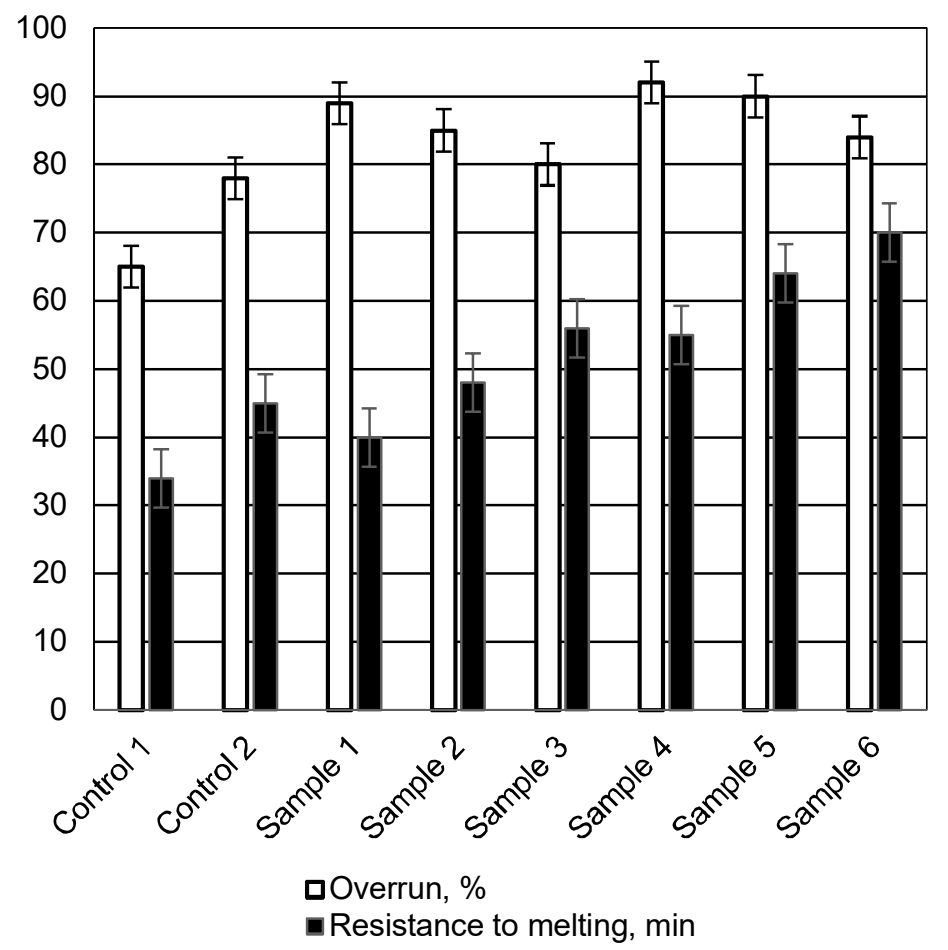

Figure 3. Overrun and resistance to melting of ice cream with and without $\beta$-glucan 
Figure 3 clearly illustrates the effect of structure stabilizers of different origins on the overrun of ice cream. It should be noted the higher foaming ability of the stabilization system Cremodan ${ }^{\circledR S I} 320$ (control 2), compared with the composition of classical stabilizers (control 1 ), due to the presence of emulsifiers-foaming agents. At the same time, the sample 1 with a content of $\beta$-glucan $0.5 \%$ shows the highest foaming ability, which is further enhanced in the presence of pectin in sample 4 . With a further increase in the content of $\beta$-glucan from $0.75 \%$ and above too strong specific mucus-like thickening of mixtures, the overrun of ice cream is somewhat reduced. Probably, long macromolecules of $\beta$-glucan to some extent mechanically limit the aeration of mixtures with its content exceeding $0.5 \%$. Thus, according to the ratio between overrun (90\%) and resistance to melting (64 min), the content of $\beta$-glucan at the level of $0.75 \%$ is rational in milk-vegetable ice cream.

As for resistance to melting, $\beta$-glucan undoubtedly has a significant effect on this indicator. There is a monotonous increase in the resistance to melting of ice cream with increasing content of $\beta$-glucan.

To explain the established effect on the peculiarities of the formation and stabilization of the foam structure of ice cream with different stabilizers, the authors further studied the microstructure of control and experimental samples of ice cream. Figure 4 shows the microstructure of ice cream on the example of a sample with classical stabilizers (control 1) and a test sample of ice cream with $\beta$-glucan (sample 5).

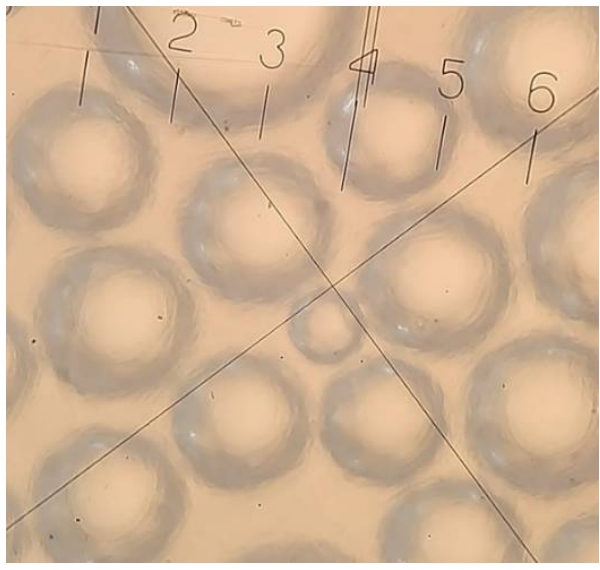

$\boldsymbol{a}$

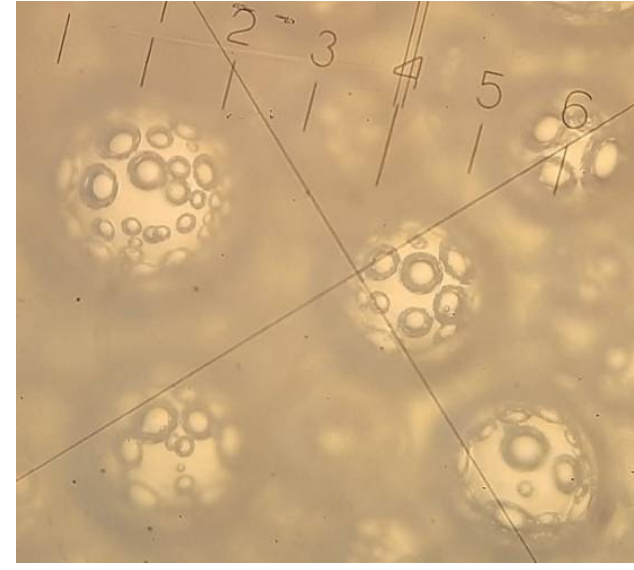

$b$

Figure 4. Microstructure of ice cream samples at a magnification of 10x15: a - control 1; b-sample 5

Figure 4 demonstrates the ability of $\beta$-glucan to form a specific secondary foam structure in soft ice cream. This microstructure is characterized by the presence of an additional framework of microbubbles, which wraps larger air inclusions. Due to the complex foam structure of ice cream with $\beta$-glucan, air bubbles acquire additional mechanical strength in conditions of positive temperatures. The foaming ability of $\beta$-glucan has been studied by other scientists (Burkus, 2000), but the ability of this polysaccharide to form a complex foam structure in ice cream has not yet been described. 
The peculiarity of foaming in mixtures in the presence of $\beta$-glucan has been revealed and is a probable reason for the increase in whipping, creamy consistency and stability of ice cream samples during heating.

Thus, according to a set of indicators of technological activity, it can be argued that $\beta$ glucan is a universal multifunctional ingredient that can, in addition to enrichment, perform structuring, foaming and stabilizing functions in dairy ice cream.

\section{Conclusions}

1. The expediency of using oat $\beta$-glucan in low-fat ice cream has been proved, which provides structuring of mixtures within the recommended values of effective viscosity and increases their thixotropic ability.

2. The complex use of $\beta$-glucan with its content from 0.75 to $1.0 \%$ and fermented vegetable puree, which contains soluble pectin and softened plant fibers, can significantly improve the viscosity-speed characteristics of mixtures: the effective viscosity increases by $11-15.9 \%$, and the degree of recovery by an average of $10 \%$.

3 . The effect of $\beta$-glucan on the overrun and resistance to melting of ice cream has been proved. Increased overrun and resistance to melting of ice cream with $\beta$-glucan are due to the formation of a specific secondary foam microstructure, which is characterized by the presence of an additional framework of microbubbles, which wraps larger air inclusions.

4. Prospects for further research are to conduct a comparative analysis of the functional and technological properties of $\beta$-glucan of different origin and varying degrees of purification in ice cream mixes, as well as to clarify the technological modes of production of ice cream with $\beta$-glucan.

\section{References}

Abdel-Haleem A. M., Awad R. A. (2015), Some quality attributes of low fat ice cream substituted with hulless barley flour and barley B-glucan, Journal of Food Science and Technology, 52(10), pp. 6425-6434, DOI: 10.1007/s13197-015-1755-x

Aljewicz M., Florczuk A., Dabrowska A. (2020), Influence of $\beta$-glucan structures and contents on the functional properties of low-fat ice cream during storage, Polish Journal of Food and Nutrition Sciences, 70(3), pp. 233-240, DOI: 10.31883/pjfns/120915

Alvarez E., Cancela M. A., Delgado-Bastidas N., Maceiras R. (2008), Rheological characterization of commercial baby fruit purees, International Journal of Food Properties, 11(2), pp. 321-329, DOI: 10.1080/10942910701359424

Antontceva E., Sorokin S., Sedykh V., Krasnikova L., Shamtsyan M. (2019), Influence of fortification of dairy products by pleurotus ostreatus beta-glucans on product characteristics, Scientific Study \& Research. Chemistry \& Chemical Engineering, Biotechnology, Food Industry, 20(3), pp. 353-364.

Armi Aghdaei S.S., Aalami M., Rezaei R., Dadpour M., Khomeiri M. (2012), Effect of isfarzeh and basil seed mucilages on physicochemical, rheological and sensory properties of ice cream, Research and Innovation in Food Science and Technology, 1(1), pp. 23-38, DOI: 10.22101/JRIFST.2012.05.21.113 
Bashir K.M.I., Choi J.S. (2017), Clinical and physiological perspectives of $\beta$-glucans: the past, present, and future, International Journal of Molecular Sciences, 18(9), p. 1906, DOI: $10.3390 /$ ijms18091906

Bass O., Polischuk G., Goncharuk E. (2017), Investigation of viscous characteristics of ice cream mixtures with starch syrup. Ukrainian Food Journal, 6(2), pp. 269-277, https://doi.org/10.24263/2304- 974X-2017-6-2-8

Borisova A. V., Makarova N. V. (2014), Retceptury morozhenogo s antioksidantnymi svoistvami s ispolzovaniem plodoovoshchnogo piure, Pishchevaia Promyshlennost, (9), pp. 18-21.

Burkus Z., Temelli F. (2000), Stabilization of emulsions and foams using barley $\beta$ glucan, Food Research International,33(1), pp. 27-33, DOI: 10.1016/S09639969(00)00020-X

Chiampo F., Tasso M., Occelli A., Conti R. (1996), Rheological properties of fruit purees, Industria Conserve, 71(3), pp. 331-336.

Du B., Meenu M., Liu H., Xu B. (2019), A concise review on the molecular structure and function relationship of $\beta$-glucan, International Journal of Molecular Sciences, 20(16), p. 4032, DOI: 10.3390/ijms20164032

El-Zeini H. M., El-Abd M. M., Mostafa A. Z., El-Ghany F. H. Y. (2016), Effect of incorporating whey protein concentrate on chemical, rheological and textural properties of ice cream, Journal of Food Processing and Technology,7(2), p. 546, DOI: $10.4172 / 2157-7110.1000546$

Giavasis I. (2014), Bioactive fungal polysaccharides as potential functional ingredients in food and nutraceuticals, Current Opinion in Biotechnology, 26, pp. 162-173, DOI: 10.1016/j.copbio.2014.01.010

Goff H.D. (2019), The structure and properties of ice cream and frozen desserts, In: Melton L, Shahidi F, Varelis P, ed., Encyclopedia offood chemistry. Elsevier, pp. 47-54, DOI: 10.1016/b978-0-08-100596-5.21703-4

Irakli M., Biliaderis C. G., Izydorczyk M. S., Papadoyannis I. N. (2004), Isolation, structural features and rheological properties of water-extractable $\beta$-glucans from different Greek barley cultivars, Journal of the Science of Food and Agriculture, 84(10), pp. 11701178, DOI: 10.1002/jsfa.1787

Javidi F., Razavi S. M., Behrouzian F., Alghooneh A. (2016), The influence of basil seed gum, guar gum and their blend on the rheological, physical and sensory properties of low fat ice cream, Food Hydrocolloids, 52, pp. 625-633, DOI: 10.1016/j.foodhyd.2015.08.006

Kosoi V., Egorov A. (2001), Reologicheskie i reometricheskie isledovaniia po opredeleniiu konsistentcii smesi i zakalennogo morozhenogo na vsekh etapakh ego proizvodstva po fiziko-mekhanicheskim kharakteristikam, Teoreticheskie $i$ prakticheskie osnovy razvitiia protcessov $i$ apparatov pishchevykh proizvodstv, Moscow, pp. 42-44.

Landikhovskaya A.V., Tvorogova A.A. (2021), Ice cream and frozen desserts nutrient compositions: current trends of researches, Food Systems, 4(2), pp. 74-81, DOI: 10.21323/2618-9771-2021-4-2-74-81

Landikhovskaya A. V., Tvorogova A. A., Kazakova N. V., Gursky I. A. (2020), The effect of trehalose on dispersion of ice crystals and consistency of low-fat ice cream, Food Processing: Techniques and Technology, 58(3), pp. 450-459, DOI: 10.21603/20749414-2020-3-450-459

Matveenko V.N., Kirsanov E.A. (2011), Viazkost i struktura dispersnykh sistem, Vestnik Moskovskogo Universiteta. Seriia 2. Khimiia, 52(4), pp. 243-275. 
Milliatti M. C., LANNES S.C.D.S. (2018), Impact of stabilizers on the rheological properties of ice creams, Food Science and Technology, 38, pp. 733-739, DOI: 10.1590/fst.31818

Nadtochii L. A., Arseneva T. P., Abdullaeva M. S., Lepeshkin A. I. (2016), Reologicheskie svoistva vysokobelkovykh smesei dlia izgotovleniia morozhenogo, Mezhdunarodnyi Nauchno-Issledovatelskii Zhurnal, 9(2), pp. 70-73, DOI: 10.18454/IRJ.2016.51.044

Polishchuk H. Ye., Martych V. V., Matsko L. M. (2014), Porivnialnyi analiz reolohichnykh pokaznykiv sumishei dlia vyrobnytstva morozyva na molochnii osnovi, Prodovolchi resursy. Seriia: Tekhnichni nauky, 3, pp. 73-78.

Polishchuk H., Sapiha V., Osmak T., Shevchenko I. (2021), Porivnialnyi analiz strukturuiuchoi zdatnosti ovochevykh piure u skladi sumishei morozyva, Naukovi Pratsi NUKhT, 27(4), pp. 154-164, DOI: 10.24263/2225-2924-2021-27-4-16

Roland A. M., Phillips L. G., Boor K. J. (1999), Effects of fat content on the sensory properties, melting, color, and hardness of ice cream, Journal of Dairy Science, 82(1), pp. 32-38, DOI: $10.3168 /$ jds.S0022-0302(99)75205-7

Rolon M. L., Bakke A. J., Coupland J. N., Hayes J. E., Roberts R. F. (2017), Effect of fat content on the physical properties and consumer acceptability of vanilla ice cream, Journal of Dairy Science, 100(7), pp. 5217-5227, DOI: 10.3168/jds.2016-12379 